\title{
Mathematical modelling on summer sesame response to moisture and thermal regimes
}

\section{K.N. SONDARVA, H.D. RANK AND P.S. JAYSWAL}

Received : 27.02.2016; Revised : 05.03.2016; Accepted : 18.03.2016

See end of the Paper for authors' affiliation

Correspondence to :

\section{K.N. SONDARVA}

College of Agricultural Engineering and Technology, (N.A.U.) DEDIAPADA (GUJARAT) INDIA

Email : kens.sondarva@ gmail.com
-ABSTRACT : A field experiment was conducted at instructional farm of soil and water engineering, CAET, JAU, Junagadh during summer season(Feb.-May). The crop was exposed to different moisture regimes by varying the irrigation interval $(3,4$ and 5 days irrigation interval) and mulch level (wheat straw mulch @ 5 t/ha and no mulch). It was observed that, sesame yield was significantly influenced by the thermal regimes and moisture regimes by varying water application under drip irrigation. The sesame yield response to seasonal thermal heat units as well as to stage wise thermal heat unit's availabilities could be described well by the quadratic model. The linear form of the model for the yield response to irrigation interval shows that the yield decreases with increase in irrigation interval. The developed model showed that for the 3 days and 4 days irrigation interval, the sesame grain yield increased more rapidly under mulch as compared to no mulch for the lower values of thermal heat units but for the higher values of thermal heat units, the yield decreased more rapidly under mulch as compared to no mulch. The sesame yield response to seasonal irrigation depth could be found linear indicating that the applied water was less than the crop evapotranspirations $\left(\mathrm{ET}_{\mathrm{c}}\right)$ or the optimal water requirements and yet there is a scope for increasing the yield by increased water application.

- KEY WORDS : Mathematical modelling, Thermal regimes, Moisture regimes

- HOW TO CITE THIS PAPER : Sondarva, K.N., Rank, H.D. and Jayswal, P.S. (2016). Mathematical modelling on summer sesame response to moisture and thermal regimes. Internat. J. Agric. Engg., 9(1) : 69-77. 